\title{
AC 2007-618: HUMANITARIAN ENGINEERING CURRICULUM: DEFINING STUDENT LEARNING OUTCOMES
}

\section{Barbara Moskal, Colorado School of Mines}

Barbara M. Moskal received her Ed.D. in Mathematics Education with a minor in Quantitative Research Methodology and her M.A. in Mathematics from the University of Pittsburgh. She is an Associate Professor in the Mathematical and Computer Sciences at the Colorado School of Mines. Her research interests include student assessment, K-12 outreach and equity issues. In 2000, she received a New Faculty Fellowship at the Frontiers in Education Conference and in 2006, she received the William Elgin Wickenden Award with colleagues, Barbara Olds and Ronald Miller.

\section{Joan Gosink, Colorado School of Mines}

Joan Gosink is an Emerita Professor and former Director of the Engineering Division at the Colorado School of Mines. Under her direction, the Division received various accolades, including designation as a Program of Excellence from the Colorado Commission on Higher Education. The program also expanded to include Masters and Doctorate degrees and an undergraduate specialty in environmental engineering. Dr. Gosink twice served as a Program Director at NSF. 


\title{
Humanitarian Engineering Curriculum: Defining Student Learning Outcomes
}

\begin{abstract}
The Colorado School of Mines through funding of the William and Flora Hewlett Foundation has established a curricular program in Humanitarian Engineering. As part of this program, four initiatives have been undertaken: 1) redesign of a core, required course for all majors, 2) establishment of an Area of Special Interest in Humanitarian Engineering, 3) establishment of a Minor in Humanitarian Studies and Technology, and 4) establishment of a Minor in Humanitarian Engineering. Decisions within this curricular development effort have been guided by the existence of a coherent and obtainable set of student learning outcomes. Faculty members are currently learning to use teaching and assessment techniques that support the attainment of these outcomes in their classroom. This paper describes the desired student outcomes for the Humanitarian Engineering program and how these outcomes have been used to guide the development of the curriculum for this program.
\end{abstract}

\section{Introduction}

There are a number of different models in the engineering education literature that describe the assessment process. These models vary based on discipline and academic level. Across most, there are four common phases to the assessment process: 1) planning the assessment process based on desired student learning (which begins with defining student outcomes), 2) implementing the assessment plan, 3) analyzing and interpreting the collected data based on a pre-defined set of performance criteria, and 4) using data to improve student learning and the assessment process itself ${ }^{1-4}$. These phases can be conceptualized as forming a continuous improvement loop ${ }^{1}$. The first phase of the assessment process can also be used as a tool that informs the development of appropriate curriculum.

Based on this model of assessment, the phases do not change due to the curriculum that is being developed. The same phases are passed through repeatedly regardless of whether the curriculum of interest concerns global knowledge, humanitarian studies or engineering statistics. The factors that do change are the desired student outcomes and, based on these outcomes, the curriculum that is developed, the instruments that are used and the interpretations that are made. This paper presents the student learning outcomes for the Humanitarian Engineering program at the Colorado School of Mines (CSM).

\section{Program Overview}

The Humanitarian Engineering program is funded by the William and Flora Hewlett Foundation through its Engineering Schools of the West Initiative grants ${ }^{5}$. Curriculum development for this project has required the collaborative efforts of two divisions at CSM: Engineering and Liberal Arts and International Studies. This interdisciplinary collaboration is creating a sequence of courses that will help engineering students to understand the ethical, cultural, historical and 
technical dimensions of engineering work applied to community development in the United States and abroad. The efforts of the "Humanitarian Engineering" initiative at CSM seek to be consistent with Accreditation Board for Engineering and Technology's criterion (3h) 6 , which states, "Engineering programs must demonstrate that their graduates have: the broad education necessary to understand the impact of engineering solutions in a global, economic, environmental, and societal context." This four-year project began at the start of the academic year 2003-2004, during which new courses, projects, and assessment activities were pilot tested.

Four curricular initiatives have been undertaken as part of this project:

1. Redesign of a core, required course.

2. Establishment of an Area of Special Interest in Humanitarian Engineering.

3. Establishment of a Minor in Humanitarian Studies and Technology.

4. Establishment of a Minor in Humanitarian Engineering.

The first initiative is the redesign of a core, required course, Nature and Human Values, in a manner that supports all CSM students in obtaining a basic global understanding as it relates to humanitarian efforts. The second initiative is the development of an area of special interest in Humanitarian Engineering. Areas of special interest at CSM are designed to allow undergraduate students the opportunity to utilize elective courses to develop specialized knowledge in a discipline outside their major. Areas of special interest require 12 credit hours of study whereas minors require 18 credit hours of study. The third and fourth curricular initiatives are the establishment of minor programs.

The first minor is in Humanitarian Studies and Technology and is offered to all majors across the CSM campus. The second minor is in Humanitarian Engineering and is primarily offered to engineering majors. The distinction between the two minors results from the curricular differences between engineering and non-engineering majors. At CSM, most engineering majors complete a six or seven credit hour required course, Senior Design, in their last semester of study. As part of Senior Design, students complete a capstone design project. Students who take the Minor in Humanitarian Engineering complete a senior design project that has a humanitarian emphasis. This requirement cannot be included in the minor offered to the broader campus, since other majors do not complete this course.

\section{Humanitarian Engineering Student Learning Outcomes}

To guide the development of the curriculum and assessment, student learning outcomes were needed for the Humanitarian Engineering program. Below is a list of these outcomes.

\section{Nature and Human Values: All CSM students will be able to:}

1. explain how engineering solutions can be used to support the basic human needs of the world's population.

2. explain how engineering solutions are impacted by the surrounding economic, environmental and societal context.

3. explain how engineering solutions may impact the global society. 


\section{Area of Special Interest: CSM students who complete the Humanitarian Engineering Area}

of Special Interest will additionally be able to:

4. explain how culture and political philosophies impact the appropriateness and sustainability of engineering solutions.

\section{Humanitarian Studies and Technology Minor: CSM students who complete the Humanitarian Studies and Technology Minor will additionally be able to:}

5. explain the influence that a given culture has had on the engineering solutions that are used in that culture (tracks: U.S., Asian, African and Middle East, Latin).

\section{Humanitarian Engineering Minor: CSM students who complete the Humanitarian Engineering Minor will additionally:}

6. design and implement an engineering solution that addresses the needs, from both a practical and cultural perspective, of a disadvantaged community.

The first three outcomes are consistent with ABET's criterion $3 \mathrm{~h}$ and are initially addressed through a one week module as part of a required core course, Nature and Human Values. In other words, all students at CSM are expected to reach these outcomes. The remaining outcomes gradually progress students who are participating in the Humanitarian Engineering program to deeper levels of knowledge and understanding. Students who participate at the more advanced levels of the program are expected to achieve all of the prior outcomes. For example, students who complete the Humanitarian Engineering Minor are expected to reach all six of the above defined outcomes.

As of the 2005-2006 academic year, ten courses have been developed and implemented as part of the Humanitarian Engineering program. Table 1 provides a summary of the new courses and how these courses are aligned with the outcomes previously described. This information was obtained through a query of the Engineers of the West assessment database ${ }^{7}$ and discussions with the Humanitarian Engineering faculty. As this table indicates, five of these courses are offered through Liberal Arts and International Studies division and five are through the Engineering Division. Eight of the ten courses are offered at a senior level; the remaining two at a junior level.

Curricular guidelines have also been established to assist students in reaching the designated outcomes. As was previously discussed, all students are expected to complete Nature and Human Values, supporting the entire CSM undergraduate population in obtaining the first three outcomes. Students who complete the Area of Special Interest have the opportunity to select from a set of courses that examine how culture and political philosophies impact engineering in various countries ${ }^{8}$. Both minors require that students complete six credit hours of specialized study on a selected culture. The cultures from which appropriate courses are available are: U.S., Latin America, Asia, and Africa and the Middle East. The sixth outcome, which is only required of students completing the Humanitarian Engineering Minor, is expected to result from the completion of a Senior Design Project that has a humanitarian component. As is indicated in Table 1, students also have the opportunity to achieve this outcome through other coursework. Details concerning the requirements of the Humanitarian Engineering Program and course descriptions are available at the project website ${ }^{8}$. 
Table 1. Course Development as a Result of Humanitarian Engineering

\begin{tabular}{|c|c|c|c|c|}
\hline Division & Level & Course & $\begin{array}{l}\text { Outco } \\
\text { mes }\end{array}$ & Brief Course Description \\
\hline \multirow{5}{*}{$\begin{array}{l}\text { Liberal Arts } \\
\text { and } \\
\text { International } \\
\text { Studies }\end{array}$} & \multirow[t]{2}{*}{ Junior } & Engineering Cultures & $2,3,4$ & $\begin{array}{l}\text { Seeks to improve students' abilities to understand and assess engineering problems solving from } \\
\text { different cultural, political, and historical perspectives. }\end{array}$ \\
\hline & & $\begin{array}{l}\text { Political Philosophy and } \\
\text { Engineering }\end{array}$ & 4 & $\begin{array}{l}\text { Students' critically explore how engineering may be related to different philosophies of the } \\
\text { common good. }\end{array}$ \\
\hline & & $\begin{array}{l}\text { Engineering Cultures for the } \\
\text { Developing World }\end{array}$ & 5 & $\begin{array}{l}\text { Seeks to improve students' understanding of engineering problem solving in the developing world } \\
\text { through historical and cultural case studies. }\end{array}$ \\
\hline & & $\begin{array}{l}\text { Technology and } \\
\text { International Development }\end{array}$ & 3 & $\begin{array}{l}\text { Students examine from a historical perspective the role of technology in humanitarian and social } \\
\text { improvement projects }\end{array}$ \\
\hline & & $\begin{array}{l}\text { Writing Proposals for a } \\
\text { Better World }\end{array}$ & 6 & $\begin{array}{l}\text { Students write funding proposals for Colorado-based nonprofit organizations that serve people } \\
\text { across the globe. This includes researching the funding agency and the community in need. }\end{array}$ \\
\hline \multirow[t]{5}{*}{ Engineering } & & $\begin{array}{l}\text { Practical Design of Small } \\
\text { Renewable Energy Systems }\end{array}$ & 4 & $\begin{array}{l}\text { Students examine practical topics related to the design of alternative energy sources, including } \\
\text { hydropower, wind power, photovoltaic, gas, biomass and energy storage, and their use in a societal } \\
\text { context. }\end{array}$ \\
\hline & & Service Learning & 6 & $\begin{array}{l}\text { Students develop an appreciation of volunteerism and examine the impact of local cultures on } \\
\text { grass root efforts. They also build a house as the final project during a week-long service trip. }\end{array}$ \\
\hline & & $\begin{array}{l}\text { Subsurface Groundwater } \\
\text { Mapping }\end{array}$ & $1,2,3$ & $\begin{array}{l}\text { Students investigate the physical properties of groundwater contaminants and surrounding media } \\
\text { with an emphasis on applying these techniques in remote or economically disadvantaged areas. }\end{array}$ \\
\hline & & $\begin{array}{l}\text { Timber and Masonry } \\
\text { Design - Applications for } \\
\text { Unconventional Materials }\end{array}$ & 5 & $\begin{array}{l}\text { Students develop an understanding of the basic engineering properties of timber and masonry } \\
\text { materials and become familiar with design methods and philosophies for timber and masonry } \\
\text { structures. This is applied to the design and analysis of structures constructed with } \\
\text { "unconventional" materials (adobe, timber pole, bamboo) such as those used in constructing } \\
\text { structures in developing countries. }\end{array}$ \\
\hline & & Understanding Landslides & $1,2,3$ & $\begin{array}{l}\text { Introduces students to the occurrence of landslides, their worldwide distributions, their triggering } \\
\text { mechanisms, their investigation and remediation, and their socioeconomic impacts. }\end{array}$ \\
\hline
\end{tabular}

Note: Labels for student outcomes:

1. Explain how engineering solutions can be used to support the basic human needs of the world's population.

2. Explain how engineering solutions are impacted by the surrounding economic, environmental and societal context.

3. Explain how engineering solutions may impact the global society.

4. Explain how culture and political philosophies impact the appropriateness and sustainability of engineering solutions.

5. Explain the influence that a given culture has had on the engineering solutions that are used in that culture (tracks: U.S., Asian, African and Middle East, Latin).

6. Design and implement an engineering solution that addresses the needs, from both a practical and cultural perspective, of a disadvantaged community. 


\section{Content, Construct and Criterion Based Knowledge}

As the above discussion illustrates, students who participate in the Humanitarian Engineering program gradually progress to more advanced levels of knowledge and understanding. The outcomes that were previously presented represent the development of different types of student knowledge: content, construct and criterion based knowledge ${ }^{9}$. The first stage of this curriculum is the completion of the Nature and Human Values. This course seeks to develop all undergraduate students' content knowledge with respect to humanitarian engineering. The second stage is the completion of an Area of Special Interest in Humanitarian Engineering. At this level, students begin to understand the constructs that underlie humanitarian studies and how these constructs impact engineering. Constructs are different from content in that the knowledge that students gain is not purely factual in nature rather students learn to apply their knowledge to various situations. The minors are further designed to advance students to use their content and construct knowledge to understand the developments in engineering within a given culture. The Humanitarian Engineering Minor takes students one step further to reflect the actual practices of humanitarian engineering, potentially increasing the consequential validity of program participation.

\section{Next Steps}

The Humanitarian Engineering curriculum is currently in place at CSM. Students are completing the programs and courses described above. The next step in this process is the evaluation of students' attainment of the desired outcomes. This is being pursued at two levels: 1) program and 2) classroom.

At the program level, the "Community Service Attitudes Scale," developed and validated by Shiarella, McCarthy, and Tucker ${ }^{10}$ is being used to measure the attitudinal changes that are taking place as a result of the revised curriculum with respect to community service. Changes in both faculty and student attitudes with respect to community service are being compared from the start of the program to when the funding concludes ${ }^{10}$. Also, placement statistics are being tracked to determine whether the number of CSM students that pursue careers with a humanitarian or global emphasis increases over the course of this project.

In the classroom, CSM engineering faculty are evaluating students' content and construct knowledge as it relates to humanitarian studies. A major benefit of the design of the Humanitarian Engineering curriculum is the inclusion of Liberal Arts and International Studies faculty. As faculty educated in the liberal arts and humanities, these individuals have the appropriate knowledge and background to assist engineering faculty in measuring the desired outcomes. This supports engineering faculty as they progress through the phases of the assessment process. As a result of Humanitarian Engineering, engineering faculty who have traditionally evaluated students' technical knowledge are now learning to use alternative forms of assessment, such as essays and scoring rubrics, that are better aligned with the desired outcomes. 


\section{Concluding Remarks}

As this paper suggests, the Humanitarian Engineering Program at the CSM is a work in progress. Given that a major component of this project is curriculum development, the work is and should be on-going. Student learning can always be improved and programs that seek to develop improved student learning do not have a natural end. As is suggested through the cyclical nature of the assessment process, these efforts should follow a continuous improvement structure with the entry point being the defining of student outcomes.

References

1. Moskal, B. "Using Assessment Results for Improving Student Learning," to appear in Constructing and Sustaining Effective Assessment in Engineering Education (working title), Spurlin, J., Rajala, S. \& Lavelle, J. (eds), Stylus Publishing, LLC.

2. McGourty, J., Sabastian, C., \& Swart, W., "Developing a Comprehensive Assessment Program for Engineering Education," Journal of Engineering Education, Vol. 87, No. 4, 355-361, 1998.

3. Rogers, G. M. \& Sando, J.K., Stepping Ahead: An Assessment Plan Development Guide, Rose-Hulman Instituted of Technology, Terre Haute, Indiana, 1996.

4. Olds, B. \& Miller, R., "Assessing a Course or Project," How Do You Measure Success?: Designing Effective Processes for Assessing Engineering Education, ASEE, Washington, DC, 35-43, 1998.

5. The William and Flora Hewlett Foundation, $\$ 10$ Million to Improve Undergrad Engineering Education in the Western U.S, http://www.hewlett.org/Programs/Education/Opportunity/News/eswiNewsRelease.htm

6. ABET, Criteria for Accrediting Engineering Programs, Online: http://www.abet.org/Linked\% 20Documents-UPDATE/Criteria\%20and\%20PP/E001\%2007-08\%20EAC\%20Criteria\%2011-15-06.pdf (accessed December 2006).Engineers of the West, Database, https://srepc.ed.unr.edu/cgibin/WebObjects/Hewlett (visited: 2/22/07, access restricted site)

7. The Humanitarian Engineering Program, Colorado School of Mines, http://humanitarian.mines.edu (visited: 2/22/07).

8. Moskal, B., Leydens, J. \& Pavelich, M., "Validity, Reliability and the Assessment of Engineering Education," Journal of Engineering Education, Vol. 91, No. 3, 2002, pp. 351-354.

9. Shiarella, A., A. McCarthy, and M. Tucker, "Development and Construct Validity of Scores on the Community Service Attitudes Scale," Educational and Physiological Measurement, Vol. 60, No. 2, 2000, pp. 286-300.

10. Bauer, E. H., Moskal, B., Gosink, J., Lucena, J. and Muñoz, D., "Faculty and Student Attitudes toward Community Service: A Comparative Analysis," Journal of Engineering Education, in press, expected April 2007. 